\title{
THE OCCURRENCE OF INGOLFIELLA IN THE EDDYSTONE SHELL GRAVEL, WITH DESCRIPTION OF A NEW SPECIES
}

\author{
By G. M. SPOONER \\ The Plymouth Laboratory \\ (With Text-figs. I-5)
}

\begin{abstract}
Among the various small Malacostraca that have lately been found living interstitially in the Eddystone shell gravel (see Spooner, I959a, $b$ ), one of the more remarkable is a new member of the genus Ingolfiella. This genus of small colourless blind amphipods occupies a very isolated position, and is customarily given the rank of a separate suborder. The six species hitherto recognized are listed in Table $\mathrm{I}$, and their geographic relationships shown in
\end{abstract} Fig. 5 (p. 328).

\section{TABLE 1. OCCURRENCE OF INGOLFIELLIDS}

\begin{tabular}{|c|c|c|c|c|c|c|}
\hline \multirow[b]{2}{*}{ Species } & \multirow[b]{2}{*}{ Reference } & \multirow[b]{2}{*}{$\begin{array}{l}\text { Geographical } \\
\text { area }\end{array}$} & \multicolumn{2}{|c|}{ Habitat } & \multirow{2}{*}{$\begin{array}{l}\text { No. of } \\
\text { specimens } \\
\text { examined }\end{array}$} & \multirow{2}{*}{$\begin{array}{l}\text { Size } \\
\text { (length, } \\
\mathrm{mm} \text { ) }\end{array}$} \\
\hline & & & $\begin{array}{l}\text { Depth or } \\
\text { height }\end{array}$ & Substratum & & \\
\hline $\begin{array}{l}\text { Ingolfiella } \\
\text { abyssi }\end{array}$ & Hansen (1903) & $\begin{array}{l}\text { North Atlantic, } \\
\text { Davis Strait }\end{array}$ & $\begin{array}{l}\mathrm{I} 870 \mathrm{fm} \\
(3420 \mathrm{~m})\end{array}$ & $\begin{array}{l}\text { Globigerina } \\
\text { clay }\end{array}$ & I & 2.5 \\
\hline I. littoralis & Hansen (1903) & Gulf of Siam & I fm ( $2 \mathrm{~m})$ & Coral sand & I & $1 \cdot 5$ \\
\hline I. acherontis & $\begin{array}{l}\text { Karaman (I933), } \\
\text { Hertzog (I935), } \\
\text { Karaman (I954) }\end{array}$ & Jugoslavia, Skoplje & c. $250 \mathrm{m \dagger}$ & $\begin{array}{l}\text { Subterranean } \\
\text { ground-water }\end{array}$ & $I^{\star}$ & $2 \cdot 5$ \\
\hline I. leleupi & $\begin{array}{l}\text { Ruffo (I950, } \\
\text { I95I) }\end{array}$ & $\begin{array}{l}\text { Belgian Congo, } \\
\text { south-east }\end{array}$ & $\begin{array}{l}\text { Above } \\
\text { rooo } \mathrm{m} \dagger\end{array}$ & Cave pools & 44 & $12 \cdot 5-14.5$ \\
\hline I. petkovskii & Karaman (I957) & $\begin{array}{l}\text { S. Jugoslavia, at } \\
\text { foot of Mace- } \\
\text { donian mountains }\end{array}$ & c. $50 \mathrm{~m} \dagger$ & $\begin{array}{l}\text { Subterranean } \\
\text { ground-water }\end{array}$ & Several & Up to $2 \cdot 0$ \\
\hline I. ruffoi & Siewing (1958) & Peru, open coast & Intertidal & $\begin{array}{l}\text { Interstices of } \\
\text { shingle }\end{array}$ & $100+$ & $I \cdot I 2-I \cdot 52$ \\
\hline
\end{tabular}

* Karaman (I957) mentions more recent additional material. This has not been reported on yet.

$\uparrow$ Above sea-level.

Of the six species, three were found in marine and three in freshwater habitats. The geographical range could scarcely be more diverse, since it includes abyssal ocean floor (and so a site that was presumably never part of a continent) and uplands on a continental shield (that may never have been under the sea), while the substratum includes both Globigerina ooze settled in quiet oceanic depths ${ }^{1}$ and shingle of a wave-beaten shore. The temperature range, as Siewing (1958) has pointed out, is also very wide.

1 A detailed analysis of the bottom on which Ingolfiella abyssi occurred is given by Boeggild (I900). 
The seventh species now to be described has been isolated from two samples of the shell gravel collected with the Forster anchor dredge, at about $25 \mathrm{fm}$, about I mile north-westward of the Eddystone Rock. One sample, collected on 3I March 1959 and cursorily examined, produced two specimens; and another, collected on 9 September 1959, of which 45 litres were examined with care, produced 18.

\section{Ingolfiella britannica sp.nov.}

With characters typical of the genus (Hansen, 1903; Siewing, 1958); body elongate, much compressed laterally; segments mostly deeper than long (cf. I. ruffoi and I. acherontis as contrasted with the more elongate I. abyssi, I. petkovskii and I. leleupi). Length of young adults and larger immature $\mathrm{I} \cdot 4-\mathrm{I} \cdot 9 \mathrm{~mm}$. (Fig. IA).

The front part of the head bears a small but definite lobe, resting in the gap between the two antennae and demarcated from the cephalon proper to which it is attached (Figs. I A, 4A), as Hansen originally describes for $I$. abyssi and I. littoralis but not found by other investigators in the species described subsequently.

Each segment of the body carries a single seta on each side of the median line in the anterior half of the segment, the position being near the centre of the segment in the urosome and progressively more anterior in the front part of the mesosome. There is also a seta on the posterior margin in the lower half of the segment. This simple setation appears to be typical of the genus.

The third urosomite appears to be capable of retraction into the second segment so that as much as nearly half of it may be lost to view (in Fig. IA it is not quite fully retracted). The rounded telson is similar to that found in other species: on each side it bears one seta and a pair of fine sensory hairs (Fig. 3J).

Antenna I (Fig. IB) bears a flagellum of four and an accessory flagellum of three segments. In the accessory flagellum the 2 nd segment is twice the length of the others (Fig. I D, cf. I. abyssi). Aesthetascs are present on the three terminal flagellar segments. In the peduncle segment $\mathrm{I}$ exceeds the combined length of 2 and 3.

Antenna 2 is typical, with five segments in the flagellum (Fig. IC).

The mouthparts (Fig. I E) agree closely with Hansen's (1903) description of $I$. abyssi. The upper lip and mandible appear not to differ; nor does maxilla 2, with five setae on its distal lobe and four on the palp (Fig. IG). The maxilla I (Fig. IF) is essentially similar: a 2-segmented palp with three or four setae terminally, a distal lobe with six toothed spines (each of an individual shape), and a short proximal lobe which appears to bear only a single seta (as in I. ruffoi). The simple maxillipede (Fig. I H) bears an elongate endite which is apt to lie hidden behind the basal segment of the 5 -segmented palp.

All seven peraeon segments have the coxopodites much reduced and scarcely protruding below the body segment; their margin carries at least one seta posteriorly, and usually a smaller one anteriorly. Only segments 3,4 and 5 bear gills: these are simple oval structures, of about a third the length of the basal segment of the limb (Fig. 3A-C).

Peraeopods I and $\mathbf{2}$ are modified as gnathopods (Fig. 2), in which, as is characteristic for Ingolfiella in contrast with other amphipods, the carpus is enlarged and the functional 'claw' composed of two segments, the propus and dactylus.

In gnathopod I (Fig. 2A) the basal segment is, as usual, broad; the carpus is elongate, subtriangular, with the 'palm' continuous with the posterior margin. The point of separation of the palm and posterior margin (opposite the tip of the dactylus) is marked by a small blunt spinous projection ( $p$ ), easily overlooked (cf. $I$. abyssi). Distalwards 


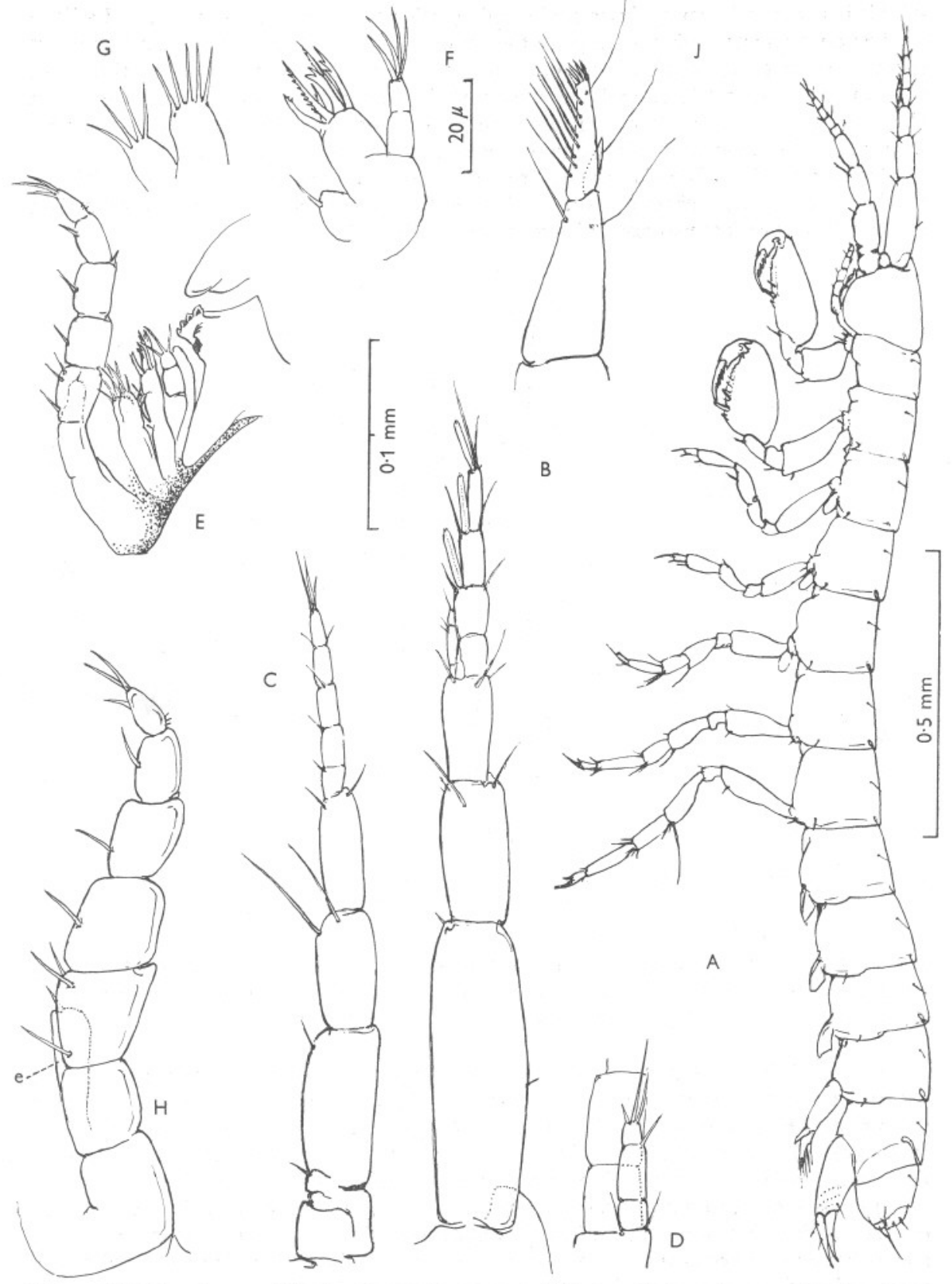

Fig. I. I. britannica. A, Whole animal of I.7I mm body length (specimen no. 5, chosen as type), probably young male; B, left antenna I; C, left antenna 2, outer view; D, accessory flagellum of antenna I enlarged; E, mouthparts seen from the side; F, maxilla I, right side, seen from the rear; G, maxilla 2, left side; $\mathrm{H}$, left maxillipede, from rear, $e$, endite; J, right uropod I of female seen from inner side, showing long sensory hairs. A, B, C, from specimen 5; D, E, from specimen II; F, G, H, from specimen 9; J, from specimen IO. The O.I mm scale refers only to $\mathrm{B}, \mathrm{C}$ and $\mathrm{J}$. 
of this is a strong linear 'palmar angle' spine, arising on the outer surface, and a little farther on a shorter spine arising on the inner surface. Along the palm a few short setae arise on each margin. The inner side of the propus is straight, but the inner margin of the dactyl is strongly serrate, with four acutely pointed teeth (apart from the elongated tip or 'nail' which might be said to make a fifth tooth). (In I. abyssi, littoralis and acherontis the dactylus of gnathopod $\mathrm{I}$ is apparently not serrate.)

The carpus of gnathopod $\mathbf{2}$ is broader and possesses a rounded palmar angle which is marked, as in I, by a short spinous projection $(p)$ (this is more strongly developed in I. abyssi). Other features are as in gnathopod I (see Fig. 2B, C).

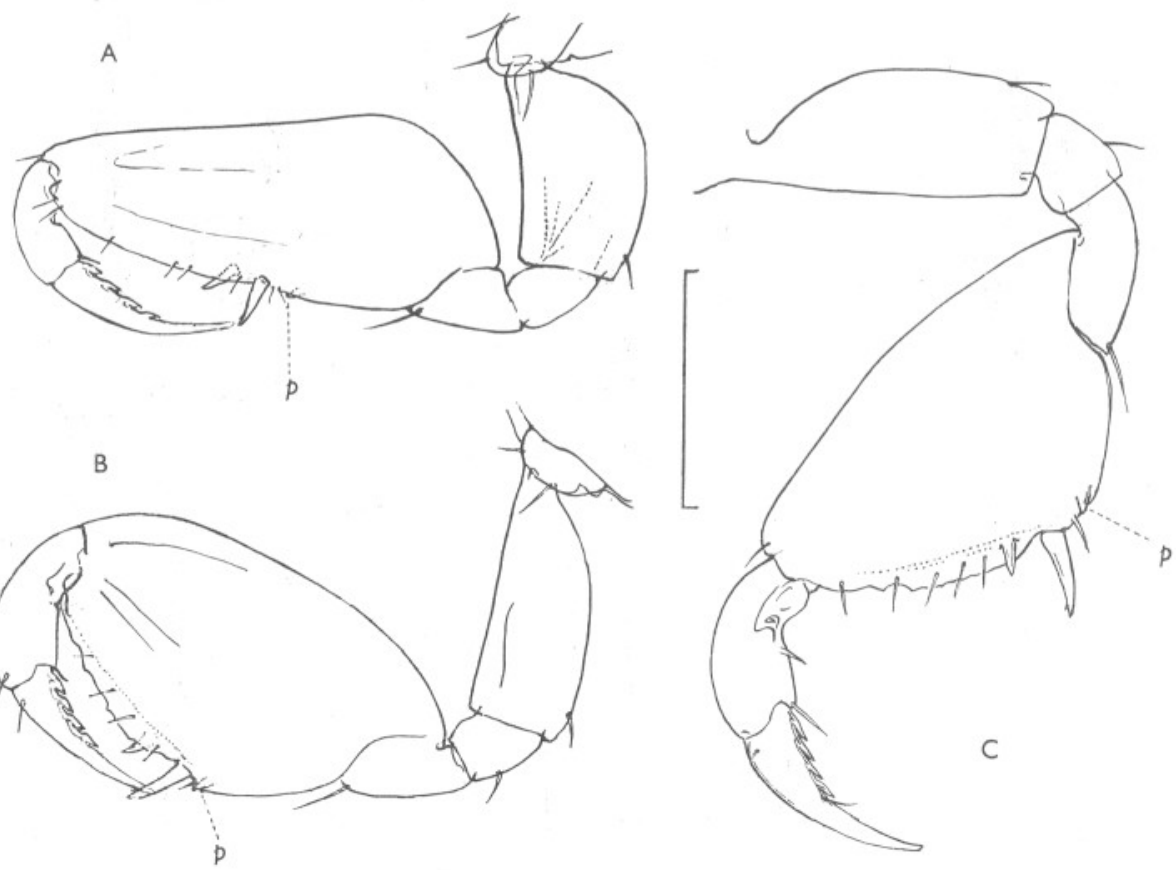

Fig. 2. I. britannica. A, Gnathopod I of left side, outer view; B, gnathopod 2 of left side, outer view; C, gnathopod 2 of right side, inner view. A and B, from specimen 5; C, from specimen 8. p, short spinous projection. The scale represents $0.1 \mathrm{~mm}$.

The remaining five peraeopods (Fig. $3 \mathrm{~A}-\mathrm{E}$ ) show progressive changes in shape, 4 and 5 being the shortest, and 7 the longest. As a series these limbs are relatively strong, markedly more so than found in $I$. ruffoi (which, however, they much resemble in shape). The terminal points of the dactyli 5-7 are all long and thin (as in abyssi, against littoralis). A stout spine arises from the posterior corner of the merus in peraeopods 5 to 7 ; in 7 it is also elongate, as long as, or longer than, the carpus, and carried in life protruding posteriorly (as shown in Fig. I). Peraeopod 7 also has a somewhat special armature at the apex of the carpus, where there is a comb of six or seven spines (Fig. 3E): apart from the slender dactylus this limb much resembles that of $I$. littoralis.

The three pairs of pleopods (Fig. 4B, C) are broadly triangular and all similar, as in $I$. ruffoi and I. abyssi. 


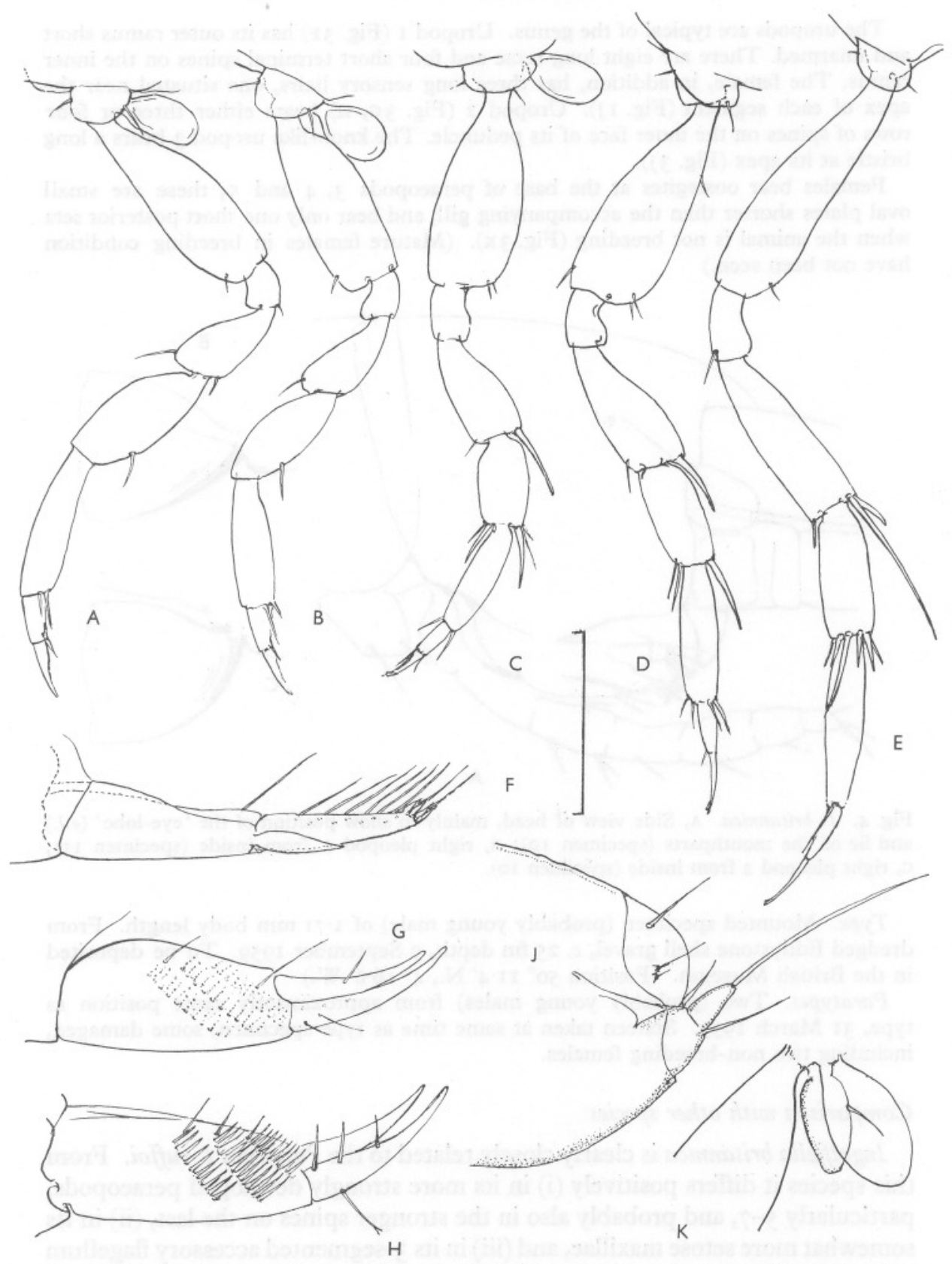

Fig. 3. I. britannica. A-E, Peraeopods 3 to 7 , left side, outer view; F, G, uropods I and 2 , left side, outer view (rows of dots represent setal comb showing through); $\mathrm{H}$, uropod 2, right side, inner view; $\mathrm{J}$, telson and uropod 3 , seen from left side; $\mathrm{K}$, immature oostegite on base of peraeopod 3. The scale represents $\mathrm{O} \cdot \mathrm{I} \mathrm{mm}$ and refers to all but $\mathrm{J}$ and $\mathrm{K} ; \mathrm{A}-\mathrm{G}$, from specimen 5 ; $\mathrm{H}$, from specimen 9 ; $\mathrm{J}$, from specimen II; $\mathrm{K}$, from specimen $\mathrm{IO}$. 
The uropods are typical of the genus. Uropod I (Fig. 3F) has its outer ramus short and unarmed. There are eight long setae and four short terminal spines on the inner ramus. The female, in addition, has three long sensory hairs, one situated near the apex of each segment (Fig. IJ). Uropod 2 (Fig. 3G, H) bears either three or four rows of spines on the inner face of its peduncle. The knob-like uropod 3 bears a long bristle at its apex (Fig. 3J).

Females bear oostegites at the base of peraeopods 3, 4 and 5 ; these are small oval plates shorter than the accompanying gill, and bear only one short posterior seta when the animal is not breeding (Fig. $3 \mathrm{~K}$ ). (Mature females in breeding condition have not been seen.)
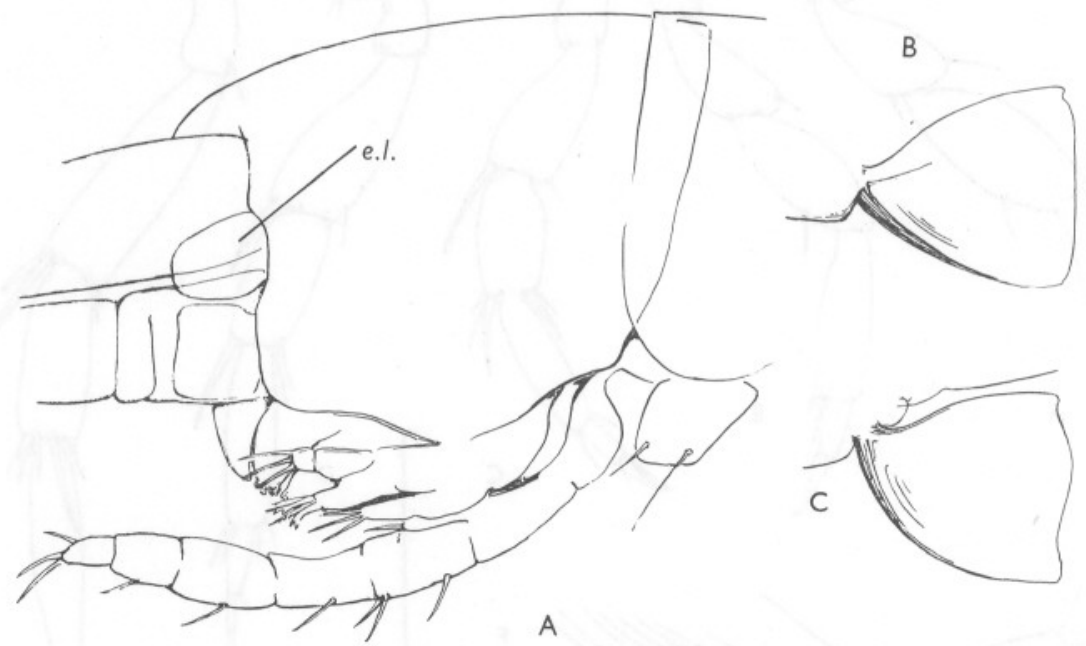

Fig. 4. I. britannica. A, Side view of head, mainly to show position of the 'eye-lobe' (e.l.) and lie of the mouthparts (specimen IO); B, right pleopod I, from inside (specimen II); C, right pleopod 2 from inside (specimen 10 ).

Type. Mounted specimen (probably young male) of I.7I mm body length. From dredged Eddystone shell gravel, c. $25 \mathrm{fm}$ depth, 9 September 1959. To be deposited in the British Museum. (Position $50^{\circ}$ II $4^{\prime}$ N., $4^{\circ}$ I6 $6^{\prime}$ W.)

Paratypes. Two (probably young males) from approximately same position as type, 3I March 1959. Sixteen taken at same time as type specimen, some damaged, including two non-breeding females.

\section{Comparison with other species}

Ingolfiella britannica is clearly closely related to the Peruvian I. ruffoi. From this species it differs positively (i) in its more strongly developed peraeopods, particularly 5-7, and probably also in the stronger spines on the last, (ii) in its somewhat more setose maxillae, and (iii) in its 3-segmented accessory flagellum (2-segmented in ruffoi). I cannot be sure that any of the other apparent differences that appear from Siewing's description of ruffoi are valid, since small features are easily overlooked. For example the absence, in ruffoi, of 
an 'eye-lobe', a maxillipede endite, and of a small spinous projection delimiting the gnathopod palm, cannot be accepted as certain: all three structures have to be carefully looked for.

From Hansen's original marine species, I. abyssi and I. littoralis, I. britannica differs in having a serrate dactylus on gnathopod I. I. abyssi differs also in its much more attenuate body-form, its more prominent spinose projection at the angle of gnathopod 2, its elongate uropod I exopodite, its smaller hind peraeopods, etc. I. littoralis has a more oval gnathopod I, stouter antenna peduncles, and marked differences in certain of the peraeopods.

The two Balkan species show no greater degree of difference although inhabiting fresh water. I. petkovskii is at once told from britannica by its more shallow body segments and peculiarly modified pleopod I (which is linear), but otherwise no very marked divergence is apparent. I. acherontis is even closer in its appearance, and, as far as its description goes, only minor differences can be noted, i.e. in lack of more than one tooth on dactylus of gnathopod I, and in the apparently more pointed shape of its pleopods. It is true that Karaman stated he failed to note an 'eye-lobe' on acherontis, and mentions none on petkovskii, but this point requires checking.

The remaining species, the larger $I$. leleupi from a cave habitat, shows several special features which distinguish it from the others, and which might justify the erection of a separate genus.

While knowledge of the genus is still so fragmentary, it is much too early to try to assess the degree of relationship between the species known to date. There must be many more awaiting discovery.

\section{Habits}

A few of the animals were alive when found, and two at least were fully active at first. They moved by wriggling movements of the body, the compressed form of which seems ideal for progress between gravel particles and in narrow crevices.

A use for the uropod setal combs was shown by one individual which repeatedly tried to clean its gnathopods with them. This behaviour involved bending the body into a loop and pressing the treated limb between the two second uropods.

\section{Habitat}

The view may be held that Ingolfiella britannica, along with certain other blind colourless forms, is a genuine interstitial animal, and may be expected to be distributed through a depth of the gravel deposit. This is probably not true for most of the many Crustacea to be obtained from the few surface centimetres of the gravel, so that evidence for the above view must be stated. 
TABLE 2. NUMBERS OF SMALL MALACOSTRACA PER 45 LITRES OF GRAVEL

9 September 1959

Agassiz trawl, Anchor dredge
subsample of $5.71 . \times 45 / 5 \cdot 7$ full count

Amphipoda

(A) A dominant surface species

Leptocheirus pectinatus

34,610

(B) Other species numerous at surface

Amphipoda

Guernea coalita

Metopid n.sp.

Socarnes erythrophthalmus

Ceradocus semiserratus

Syrrhoid n.sp.

Eurystheus lobatus

Gitana sarsi

Leptocheirus tricristatus

Idunella n.sp.

Megamphopus cornutus

Maera othonis

Metaphoxus fultoni

Liljeborgia kinahani

Cressa dubia, etc.

Leucothoë sp., etc.

Misc. (Apherusa, Nototropis, Sympleustes,

Perierella, Normanion, etc.)

$\begin{array}{rr}726 & 36 \\ 719 & 58 \\ 647 & - \\ 632 & 3 \\ 458 & 4 \\ 237 & - \\ 205 & 4 \\ 205 & 1 \\ 118 & 3 \\ 55 & 4 \\ 47 & - \\ 40 & - \\ 40 & - \\ 16 & - \\ 16 & 3 \\ 40 & -\end{array}$

Isopoda, Tanaidacea, and Cumacea

Paramunna bilobata

Typhlotanais microcheles

I973

Strongyurella indivisa

$\begin{array}{rr}\text { I973 } & 52 \\ 324 & 8 \\ 205 & 57 \\ 189 & 5 \\ 174 & 6 \\ 142 & 8 \\ 118 & 1 \\ 95 & 5 \\ 24 & 1 \\ 16 & 2 \\ 8 & 1 \\ - & 263 \\ 7,469 & \end{array}$

Gnathia oxyurea

Cumella n.sp.

Eurycope pygmaea

fanira maculosa juv.

Nannastacus spp.

Paratanais batei

Microniscid larvae

Eurydice pulchra, etc.

Leptognathia sp.

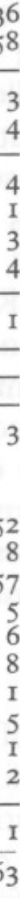

(C) Interstitial species distributed through gravel from surface downwards

Amphipoda

Bogidiellid n.gen., n.sp.

Isopoda

Microcharon harrisi

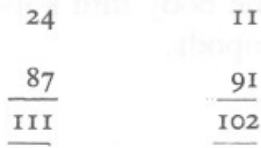

Amphipoda

Bogidiella n.sp.

Ingolfiella britannica

Tanaidacea

Strongylura n.sp.

Total per 451 . of gravel

42,190 
When the shell gravel has been collected with the Agassiz trawl (now a routine method) which scrapes the surface or at least digs quite shallowly, a density of several hundreds of small Malacostraca is obtained per litre of gravel (evidence from hauls of 15 September 1958, 21 October 1958 and 9 September 1959). Perhaps forty species, of differing abundance, may be got in a haul of 301 . By contrast, when the more deeply digging Forster 'anchor dredge' is used the equivalent density of Malacostraca is only about Io per litre of gravel. After an indication of this state of affairs had been got from a haul on 3I March I959, a careful examination of a large sample (45 1.) taken on 9 September 1959 produced only 436 of these animals. The Agassiz haul, by contrast, collected on the same day, gave a figure of over 42,000 per 1. of gravel, as shown in Table 2 .

In the 'anchor dredge' sample some species living on or close to the surface are evidently included, but the sample is probably biased towards a depth of between Io and $20 \mathrm{~cm}$ (since it was deliberately taken from the apex of the bag). The composition of this fauna shows a marked preponderance of blind colourless species, and an appreciable proportion of five forms that may be supposed to be genuinely interstitial and surface-avoidingnamely Microcharon, two bogidiellids, Ingolfiella, and an unknown Strongylura with an unusually elongated metasome. Two of these species (group $\mathrm{C}$ in Table 2) appear to be equally distributed through the depth of gravel investigated, and the other three, including Ingolfiella, seem to avoid the immediate surface of the gravel (group D). None of the group D species have yet occurred in gravel from Agassiz hauls, and for these species at least it can be said that an increase has been found below the surface, albeit the density may remain low even in favourable sites.

\section{DISCUSSION}

The recognition of special interstitial forms living in offshore marine deposits raises a further issue. On land, where observation is easier, there is growing evidence of continuity between the faunas of interstitial water, wells, springs, cave pools, underground streams, etc., for the reason that all these habitats are special branches or extensions of the general subterranean water-table through which some species are readily dispersed and others are at least capable of spreading during many generations. There thus arises the notion of a 'hypogean' fauna occupying the not-so-discontinuous medium of subterranean ground-water. May not this be equally true of the terrain below the ocean floor?

Perhaps, indeed, the interstitial fauna of bottom deposits is but the fringe of a more widespread fauna dispersed through rocks below the sea bed, and this supposed 'submarine hypogean' fauna merges with the 'subterrestrial hypogean' of which something is already known. (It may also have broad 
continuity with the smaller fauna of the dark ocean floor, as does the subterranean fauna with that of deep lake bottoms.) Belief that this indeed may be so is encouraged by the fact that certain malacostracan genera (Microcharon, Bogidiella) now found to be interstitial in marine deposits are already familiar from continental sites.

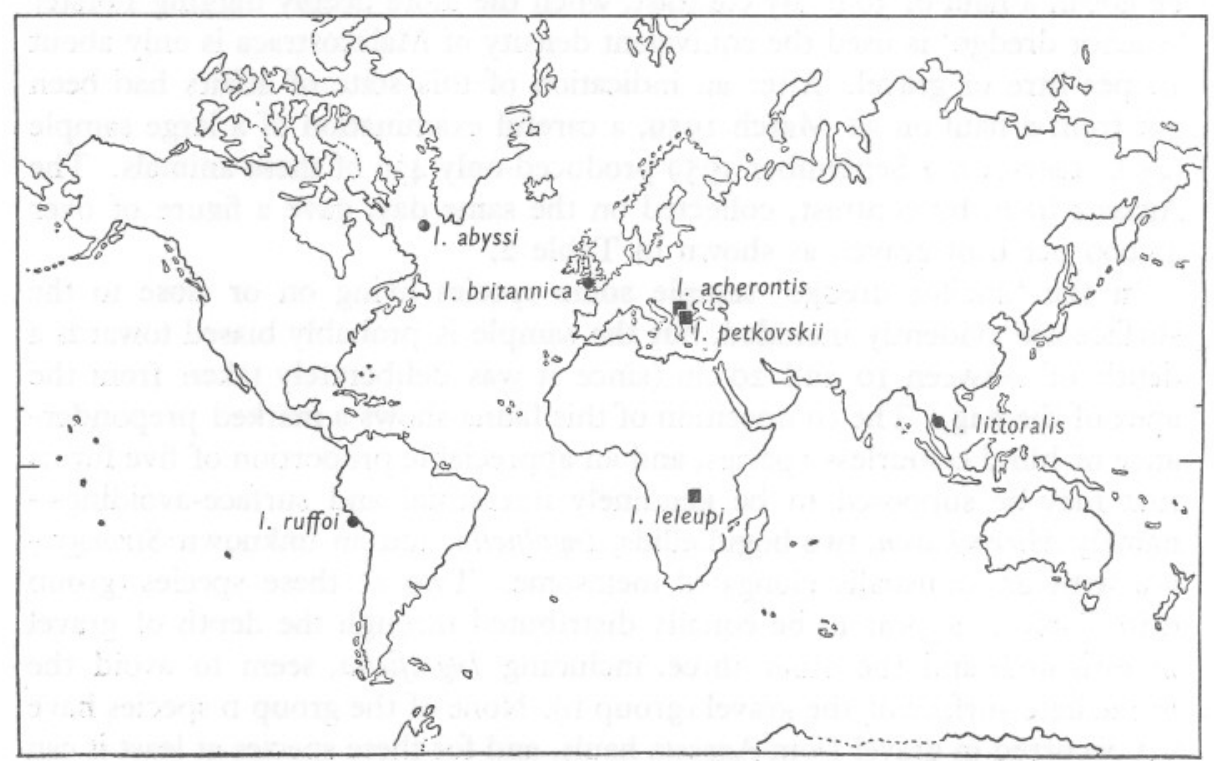

Fig. 5. Distribution of known species of Ingolfiella (see Table I).

- Marine habitats; freshwater habitats.

The problem presented by what is already known of the distribution of the Ingolfiellidae would now become intelligible. The recorded habitats are just some of the many possible outposts, the links between which are not to be found in the seas and surface waters, but in the sub-surface waters that extend beneath both continents and oceans. In this 'hypogean' domain it is supposed that a slow spread and evolution of species has taken place, particularly of a few specialized groups including the ingolfiellids.

On this hypothesis the best chance of finding extensions of range of known species, and the existence of others yet unknown, is to explore hypogean waters. But how to investigate them below the floor of even shallow seas, let alone that at greater depths, presents a formidable oceanographic problem.

\section{SUMMARY}

Ingolfiella britannica is described from the Eddystone shell gravel. It is the seventh species of a genus whose distribution has a cosmopolitan aspect, and which occupies an isolated taxonomic position in the Amphipoda. 
The species possesses a distinct 'eye-lobe' on the side of the head between the two antennae, as originally described by Hansen for $I$. abyssi and $I$. littoralis, but not seen by subsequent authors in four other species. This is an articulated flap, of very obscure morphological significance.

I. britannica is evidently a true 'interstitial' animal, along with certain other Crustacea occurring with it.

An explanation for the peculiar distribution of Ingolfiella is to be sought in the continuity of the 'hypogean' fauna under continents and oceans alike.

\section{REFERENCES}

Boeggild, O. B., I900. Deposits of the sea-bottom. Dan. Ingolf-Exped., Vol. I, Pt. 3, 91 pp.

HANSEN, H. J., I903. The Ingolfiellidae, fam.n., a new type of Amphipoda. F. Linn. Soc. Lond., Vol. 29, pp. I17-33.

HertzoG, L., I935. Amphipoden aus dem Grundwasser von Skoplje Bogidiella albertimagni mihi und Ingolfiella acherontis (Karaman). Zool. Anz., Bd. III, pp. 50-2.

KARAMAN, S. L., 1933. Über zwei neue Amphipoda, Balcanella u. fugocrangonyx aus dem Grundwasser von Skoplje. Zool. Anz., Bd. I03, pp. 4I-7.

- 1954. Über unsere unterirdische Fauna. Acta Mus. Maced. Scient. Nat., T. I, (No. 9) pp. 195-215.

- I957. Eine neue Ingolfiella aus Jugoslavien, Ingolfiella petkovskii n.sp. Folia Balcanica, T. I, (No. 7) pp. 35-8.

RufFo, S., I950. Considerazione sulla posizione sistematica e sulla distribuzione geografica degli Ingolfiellidi. Boll. Zool. Turin, Vol. 17, pp. 65-73.

- I95I. Ingolfiella leleupi n.sp., nuovo Amfipodo troglobio del Congo Belga. Rev. Zool. Bot. Afr., Bd. 46, pp. I89-209.

SIEwING, R., 1958. Ingolfiella ruffoi nov.spec., eine neue Ingolfiellide aus dem Grundwasser der Peruanischen Küste. Kieler Meeresforsch., Bd. I4, pp. 97-IO2.

SPOONER, G. M., I959a. The occurrence of Microcharon in the Plymouth offshore bottom fauna, with description of a new species. F. mar. biol. Ass. U.K., Vol. 38, pp. 57-63.

I 1959 b. New members of the bottom marine fauna. Nature, Lond., Vol. I83, pp. 1695-6. 